\title{
Anchors of Colonial Rule: Pluralistic Courts in Java, ca. 1803-1848
}

\author{
SANNE RAVENSBER GEN* \\ E-mail: s.ravensbergen@hum.leidenuniv.nl
}

Through an institutional approach and by focusing on long-term developments, this article offers a genealogy of the pluralistic character of the landraad (regional colonial court) in colonial Java. It argues that the pluralistic landraden — consisting of a Dutch president, Javanese judges, a local prosecutor, and Islamic and Chinese adviserswere crucial to the process of colonial state formation. This long-term process reflects continuities rather than rupture and change between the era of the VOC and the nineteenth-century developing colonial state. The spatial sites of the landraden reveal not only the conflicts between several layers, institutions, and individuals in the process of colonial state formation but also the importance of local actors in this process. Local dynamics as well as tensions between the various layers of the colonial state, which were striving either for uniformity or for the maintenance of local pluralities, provide insights into the complex formation processes of dual rule from below.

Keywords: Legal history, colonial state formation, Java, Indonesia, legal pluralism.

On the night of 28 October 1834, in a village in the vicinity of Batavia, a burglary was committed in the house of a local woman named Njai Djora. The loot consisted of a copper rice kettle, a knife, half a bushel of rice and - to complete dinner-some bananas. Shortly thereafter, the grass cutter Badak and gardener Djanoesien Singke were arrested on suspicion of having committed this and another burglary. On Wednesday 3 December of the same year, they appeared before the landraad (plural: landraden). This law court was presided over by the Dutch assistant resident Fredrik Doornik, and present in the role of court members were the overseer Abdul Rahiem, Captain Abdul Haliem, and Lieutenant Mohamat. The position of registrar was fulfilled by Lucas Bruijninga. The two suspects were brought inside the courtroom, after which the prosecutor, Adjunct Jaksa Johan Abiedien Naija Gatie, ${ }^{1}$ announced the indictment. A gardener, a female merchant, a female dancer, and a Chinese guard of the bazar were interrogated as witnesses. After these depositions, the adjunct jaksa and the Islamic adviser Chief Penghulu Fakier Abdul Moedjied Jubidie ${ }^{2}$ were asked for their advice-based on Javanese-Islamic laws and customs - on the guilt of the suspects and a suitable punishment. Both agreed that while the guilt of Badak had 
been proven, there was insufficient proof of the guilt of Djanoesien Singke. Regarding Badak's punishment, the penghulu advised "cut[ting] off the right hand." In response, the jaksa referred to a colonial regulation abolishing all cruel and mutilating punishments and advised imposing thirty rattan strokes and four years in a chain gang in Java. ${ }^{3}$ The assistant resident and the Javanese members together decided on the verdict behind closed doors. The verdict shows they followed the advice of the jaksa. Badak was found guilty and sentenced to thirty rattan strokes and four years of chain gang. Djanoesien Singke was acquitted and released immediately. ${ }^{4}$

This criminal case from 1834 portrays a landraad in full swing, and brings to the fore the pluralistic character of the courtroom, with multiple actors and laws active during the proceedings. The landraden in nineteenth-century Java were the "regular daily judges" of the local population in most criminal cases. ${ }^{5}$ They were collegiate courts, in which a European administrative official (or, after 1869, a Dutch judge) functioned as the president, with a majority of at least two Javanese officials appointed from the regional Javanese elite as court members. The Dutch and Javanese court members decided the case by ballot. During the court session, the Javanese jaksa, the Javanese-Islamic penghulu, and the Chinese captain provided legal advice regarding "local and religious customs and laws." ${ }^{6}$ The landraad in this form had its origins in the eighteenth century and would continue to exist until 1942. They were the only sites in colonial Java where the representatives of most regional European and non-European elites came together while on duty, and they decided on the verdict together. Consequently, legal pluralities were forged and the perspectives of Dutch and Javanese officials, as well as Chinese captains and Javanese-Islamic advisers, all influenced the law court sessions. ${ }^{7}$

Despite its long life and its pluralistic character, the landraad has not been extensively researched. ${ }^{8}$ In contrast to the rich literature on the contested and conflicted nature of legal pluralism in the British Empire, for colonial Indonesia, legal history is an understudied field and, moreover, the conceptual framework of legal pluralism has only been mobilised to designate the segregated character of the Dutch colonial legal system. ${ }^{9}$ In this segregated legal system, different population groups were tried by different courts and different laws, a policy that served the politics of difference. Yet, the role of legal pluralities and hybrids within the segregated legal system and its relationship to the jurisdictional politics of difference and colonial state formation has been largely overlooked.

Through an institutional approach and by focusing on long-term developments, this article offers an institutional genealogy of the pluralistic character of the landraad. ${ }^{10} \mathrm{I}$ argue, first, that legal pluralities within the segregated legal system, in the form of pluralistic courts - most prominently the landraden - were crucial to the process of colonial state formation, and second, that this role of pluralistic courts within colonial state formation reflects continuities rather than rupture and change between the era of the Verenigde Oost-Indische Compagnie (VOC) (1602-1799) and the period of the developing colonial state in the Netherlands Indies (1800-1942). ${ }^{11}$ 


\section{Courts and the Colonial State}

After arriving on the island of Java in the seventeenth century, the Dutch gradually interfered in, and ultimately overruled, the different existing Javanese kingdoms and sultanates. In the nineteenth century a colonial state in Java was still in the making, as was an economy built on the large-scale export of agricultural products deemed essential for the Dutch economy. Sugar factories, tea plantations, and a growing rural Javanese population as the labour force dominate histories of this century, but the daily lives of the Javanese were shaped by the developing colonial state in other ways as well. Driven by an urge for organising the colonial state in a uniform manner while simultaneously securing the position of the Javanese elites, the Dutch significantly transformed local courts and laws. In return, the colonial state was itself continuously transformed by various local dynamics.

State formation is a complicated process in general. After all, the state doesn't exist and its process of formation is never linear, as states consist of several sources, institutions, and layers of power that often contradict and compete with each other. ${ }^{12}$ Moreover, colonial state formation followed a unique path, being a particularly diffuse process of interacting local and colonial sources and layers of power caused by the conflicting aims of metropole and colony, of different colonial state institutions, and of colonial and local elites. ${ }^{13}$ The tensions between the colonial governments in The Hague and Batavia, regional administrators, and the colonial Supreme Court and local pluralistic law courts all shaped the state in Java. Research into colonial state formation leads to questions about indirect and direct rule, brokerage, and colonial knowledge. ${ }^{14}$

These questions are certainly relevant regarding nineteenth-century Java, where the colonial state was characterised by a system of dual rule - a policy between direct and indirect rule - in which the administration was divided into two branches. ${ }^{15}$ The Javanese branch consisted of local Javanese elite families whose members were appointed as officials (priyayi). They governed the Javanese population, were responsible for police affairs, and executed colonial policies. The Dutch branch consisted of Dutch officials, who were temporarily appointed in the residencies. They governed the European population and directed the priyayi in their responsibilities. The priyayi were traditional local elites - the position of the regent (the highest priyayi) was made hereditary under Dutch rule_-but functioned simultaneously as colonial officials who could be transferred and dismissed by the colonial government. $^{16}$

The division of labour between the Javanese priyayi and the Dutch officials, however, did not lead to two completely separated worlds, since there were, inevitably, moments of contact, encounter, and collaboration in order to establish and maintain rule. ${ }^{17}$ In the courtroom these complexities became visible and the courts themselves were also part of the process of the formation of dual rule and the colonial state. Even though in principle, according to the ideal of dual rule and a segregated legal system, Javanese priyayi administered justice over cases in which no Europeans 
were involved, an exception was made for law cases considered to be important for the reinforcement of colonial rule - mainly criminal cases. These were administered by pluralistic courts - such as the landraden — presided over by a Dutch official who decided the verdict together with at least two Javanese priyayi. The complexity of the colonial state in Java - based on dual rule (priyayi and Dutch officials) and the collaboration with other local elites such as Chinese captains and Islamic penghulus - is reflected in the landraden and its legal pluralities.

A focus on the encounters between officials from different backgrounds at the pluralistic landraden and the related moments of contact and conflict offer opportunities to study the "tensions of empire" on a regional level and, moreover, provide insights into how these tensions shaped the colonial state itself. ${ }^{18}$ Pluralities were not odd singularities of a centralising state, but a phenomenon that was part of the state processes, or in the words of legal historian Paul Halliday, "the early modern state was not simply a site of pluralities. It was made by them." ${ }^{19}$ At the same time, the process did move in the direction of more state control over jurisdictions, and consequently local authorities and laws were identified and written down, with alterations and codification as a result. ${ }^{20}$ The tensions between the various layers of the colonial state that were striving for uniformity, or for the maintenance of local pluralities, provide insights into colonial state practices and the complex formation processes of dual rule from below.

\section{The First Landraden in Java}

The VOC accepted and applied legal pluralities early on when administering justice over local populations in the areas they controlled in the Indian Ocean world. Although at the centre of VOC power in Batavia an official policy stated that European law and VOC-regulations would judge all inhabitants, in practice this was also a plural world. Non-European witnesses in the Schepenbank (Court of Aldermen) took an Islamic or Chinese oath, and during the early seventeenth century Chinese members were seated in the court. ${ }^{21}$ Outside Batavia, the Dutch encountered various legal landscapes that had their own trajectories of development and contestations, such as jurisdictional co-existence as well as conflicts between Islamic and local judges, the penghulus and jaksas. All this was not an entirely unfamiliar encounter, however, since legal pluralities and regional differences were common in the Dutch Republic itself. In 1813, there were no less than 128 criminal law courts in the province of Holland that allowed different systems of adjudication. ${ }^{22}$

Outside of the directly governed VOC-areas, the Javanese legal systems formally remained the full responsibility of the local rulers, but several attempts to codify local laws occurred and some meddlesome VOC officials intervened in local law courts. ${ }^{23}$ The first official landraad in Java was set up in 1747 for the rural areas in the Semarang area, due to expanding VOC influence on the Northeast Coast of Java in the mid-eighteenth century. The inhabitants of the city of Semarang remained subject to Dutch laws and the Council of Justice, whereas the landraad administered justice 
over all Javanese who resided in the large Northeast Coast region and were not subjected to the Mataram kingdom. The landraad decided over civil and criminal cases between Javanese and Javanese exclusively. ${ }^{24}$

The Semarang landraad drew from the VOC experience in Ceylon both in the figure of Governor General Gustaaf van Imhoff (1743-50), who was a recent arrival from Ceylon, and the structure of these courts. However, the landraad of Semarang was not an exact copy, but adjusted to Javanese circumstances. At the landraad of Galle (South Ceylon), for example, the emphasis was on civil law, as in this region land law was important for the VOC. ${ }^{25}$ In Semarang, maintaining order and peace was the incentive to establish the landraad, and the emphasis was on criminal justice. Another difference was that the local chiefs of Ceylon were attached to the landraad as advisers, whereas in Java the Javanese regents voted on the verdict. The landraad of Semarang consisted of at least seven Javanese regents and was presided over by the European governor. The chief jaksa was the public prosecutor. The cases had to be decided according to the "Javanese laws" insofar as they were "acceptable" to the Dutch. ${ }^{26}$ The regulations mention nothing about a role for the penghulus in the Semarang landraad, although the Dutch asserted that the Semarang Compendium, a code compiled especially for the landraad, was drawn from Islamic law. ${ }^{27}$

The Dutch would continue collecting customary Javanese and Islamic laws during the eighteenth century to be used by the local courts as sources of law. By doing so the Dutch created static archives that were considered to be Javanese or Islamic. In Batavia, the supposedly Islamic Frijer Compendium would be compiled in 1761, whereas in the sultanate of Cirebon (West Java) local laws were collected and published as the Javanese Pepakem Cirebon in 1765.

The influence of the VOC on criminal law practice in Cirebon dated back to the early eighteenth century. A judicial-administrative council - the meeting of the sultansdealing with criminal cases consisted of Javanese members and was presided over by the Dutch resident. The resident was entitled to make the final decision over the verdict if he received orders from Batavia to do so, or on his own initiative. Another indicator of the influence of the VOC in Cirebon was a change in the procedure for presenting evidence. According to local traditions, evidence was offered by oral expert witness accounts, historical information, and natural landmarks. Around 1740 this system of evidence in Cirebon was completely replaced by written documents that referred to a proces-verbaal and Javanese-Dutch legal texts. ${ }^{28}$ Simultaneously, however, Islamic law was increasingly influential in Cirebon, causing the religious penghulu courts to become more important than the Javanese jaksa courts. ${ }^{29}$

Thus, halfway through the eighteenth century the VOC had transformed the administration of justice in Java through the establishment of a landraad in Semarang and through interventions in the administration of justice in Cirebon. Given the major differences between Semarang and Cirebon, the courts that the VOC altered or introduced were also distinct. In Cirebon, there were four sultans. In Semarang, the seven regents of the Northeast Coast were important. However, despite regional differences, there were also important similarities between the courts of the two 
regions. First, they were pluralistic, with Javanese judges in the majority. Second, in both instances, justice over the Javanese population was administered according to local laws and customs, though influenced by European laws and customs. Third, in both councils the emphasis was on criminal cases, which were deemed to be of the highest importance for colonial rule in Java. Fourth, there was no separation of powers and the courts were subject to political influence. Finally, in Java there was a slow but steady increase in the number of colonial courts.

\section{A Persistence of Pluralities}

Political instability, the arrival of the VOC, the growth of Islam, and local circumstances all altered the Javanese legal systems in different ways during the eighteenth century. This dynamic process was still ongoing when the VOC collapsed in 1799. The Dutch government adopted the VOC possessions in the Indonesian archipelago and - with a short but important British interlude from 1811 until 1816-transformed them into a colonial state during the nineteenth century. This process of colonial state formation involved the introduction of an extensive uniform colonial legal system in Java. Yet the continuities with the VOC period are notable.

In 1803 a transitional commission presented the Asian Charter that laid out the foundations of the "new" colonial state. The Charter's advice on the legal system regarding the local population was threefold. It urged an increase in the number of law courts; it recommended that the local population be judged according to their own laws and customs; and it called for the removal of political influence from the legal system. ${ }^{30}$ The Charter was never implemented in practice, but Governor General Herman Willem Daendels (1806-1810) would use it as an inspiration for his reforms.

Daendels's rule has been designated as a "turning point" centralisation reforms, but with regard to the law courts it is important to note that he decided to maintain the regional diversities inherited from the VOC period. Each landraad retained its own characteristics. The landraad of Semarang was in the early nineteenth century still active in the same setting as during the eighteenth century. Smaller courts were established at the northeast coast area of Java to administer justice over smaller cases. The landraad in Cirebon seems to have been a continuation of the judicial-administrative council presided over by the resident, although Islamic legislation and advisers were incorporated into the court. ${ }^{32}$ New landraden were established in Surabaya and Banten, each also adjusted to local circumstances. In the landraad of Banten, for example, which had been brought under Dutch rule in 1808 , the Javanese members were the rijksbestierder (local "prime minister") and two kliwongs (districts chiefs). The penghulu offered advice. ${ }^{33}$ Whereas the landraad in Banten judged solely in criminal cases, the landraad of Cirebon also administered justice in civil cases. ${ }^{34}$

From 1811 to 1816, the British controlled Java. Governor General Thomas Stamford Raffles attempted to further curb the power of the Javanese elites. He 
attacked the palace of the sultan of Yogyakarta; the sultan of Banten was forced to cede land; and the sultans of Cirebon surrendered their remaining independence. ${ }^{35}$ Regarding the legal system, whereas Daendels had adjusted the pluralistic law courts according to regional differences, Raffles imposed a significantly more uniform court system by introducing identical landraden, where the Javanese members were demoted to the role of assessors in an advisory role and the colonial resident became the single judge. ${ }^{36}$ Whereas Daendels had merely appointed the Islamic penghulus as legal advisers, Raffles decided to ask both the penghulus and the jaksas for their advice in landraad cases. Another important reform was the introduction of circuit courts for capital crimes, since these travelling courts were presided over by trained lawyers instead of an administrative official. ${ }^{37}$ In this court, the British jury system was introduced and the jurors of the circuit court were at least five men who "ought to be as near on an equality, as to rank in life, with the prisoner, as possible. ${ }^{\prime 38}$ Although the introduction of circuit courts caused the legal system to become more independent in capital cases, regarding the landraden there was no abandoning of the Dutch policy of acknowledging Javanese rulers and chiefs and maintaining local customs. ${ }^{39}$ Despite Raffles' vigorous attempts to introduce a uniform legal system in Java, he did not let go of the pluralistic character of the colonial courts, although the Javanese court members became advisers in the landraad rather than judges.

This last reform was reversed when Java was regained by the Dutch, who were quick to rehabilitate the Javanese priyayi as court members entitled to vote in the landraad. ${ }^{40}$ Javanese priyayi were also installed as court members in the circuit courts, and the jury system - unfamiliar to Dutch legal culture — was abolished. The Dutch maintained the double advisory role of the penghulu and jaksa. The increase of pluralistic courts also continued and in 1824 the landraden were even introduced in urban Java (Batavia, Semarang, and Surabaya). ${ }^{41}$ This also marked the completion of the segregated legal system, because now all non-Europeans went to different law courts than the European population. ${ }^{42}$ In 1846 , Chinese captains were added to the landraden and circuit courts as advisers in cases in which a Chinese was involved. ${ }^{43}$

In the first half of the nineteenth century, the number of landraden in Java rapidly increased from two in 1800 to sixty-two in $1848 .{ }^{44}$ In that year, it was decided that landraden would also be established outside of the capital towns of the residencies wherever necessary, and by 1874 there were eighty-nine landraden in Java. ${ }^{45}$ The frequency of court sessions also intensified. Whereas during the eighteenth century the landraad of Semarang only gathered once a year, in 1838 Pfyffer zu Neueck mentions in his travel account that landraad sessions in Java were held "almost every month." ${ }^{46}$ The landraad of the crowded Batavian suburb of Meester Cornelis shows an even higher frequency; in 1834 court sessions were held each Wednesday. ${ }^{47}$ From 1848, all landraden were obliged to hold sessions at least once a week and besides that as often as possible. ${ }^{48}$ In the early twentieth century, many landraden held sessions on a daily basis, and due to the introduction of landraad vice-presidents, two sessions could be held simultaneously. ${ }^{49}$ 
During the first decades of the nineteenth century, Daendels and Raffles laid the basis for an extended network of landraden organised according to a similar design. Yet there was no clean break with the eighteenth-century practices of criminal justice, since basic principles of the landraad remained the same: justice was applied by a majority of Javanese judges in the pluralistic law courts, the Javanese population was theoretically still tried according to their 'own' laws and customs, and the emphasis remained on criminal law. There was also still no separation of powers ${ }^{50}$ and, finally, the increase in the number of landraden continued, although taking place at a much higher pace. Altogether, the eighteenth-century landraden in Cirebon and Semarang were a direct prelude to, first, the segregated dual legal system as it expanded during the early nineteenth century and, secondly, to the existence of pluralistic courts within the "native branch" of this segregated system.

\section{Pluralities in Practice, 1819-48}

Since the landraden were firmly rooted institutions in Java, studying their pluralistic practices offers insights both into dynamics at the local level and into the interactions between the various layers of the colonial state. Procedural documents of landraad cases easily debunk the stereotypical Dutch depictions of local officials and bring to the fore their importance, but also show their marginalisation, their struggles, and their agendas. The penghulus, for example, were often portrayed by Dutch officials as always recommending cruel punishments. Islamic law was depicted as particularly cruel, and this was used as an excuse to ignore the penghulus' advice. Procedural documents show, however, that it was certainly not always the case. ${ }^{51}$ On 16 January 1826 , for example, there was a difference of opinion between the penghulu and the jaksa of the landraad in the West Quarters of the environs of Batavia (Tangerang). The penghulu recommended a (relatively mild) punishment of no more than thirty rattan strokes for the farmer Oetan Bappa Leha, who had stolen food to feed his family, who had not eaten for five days. The jaksa pleaded for three years of chain labour. Due to a positive statement by a local overseer, Oetan Bappa Leha was sentenced by the three local court members and the Dutch president to a punishment milder than the jaksa's recommendation, although the verdict was still harsh: thirty rattan strokes, to be executed at the bazar of Tangerang, and chain labour for one year. He also had to return the stolen rice. ${ }^{52}$

The abovementioned case, and the criminal case described at the start of this article, show that different actors were involved in the process of coming to a verdict, and also that the legal advice provided by the penghulu might be contested, yet still was sought. Sources from the early nineteenth century expose how local dynamics were further complicated by jurisdictional and political conflicts among layers of the colonial state. The application of local laws, although formally required, came under pressure because of legal supervision by the Supreme Court in Batavia. The official policy of separated jurisdictions for Europeans and non-Europeans was derived from 
the belief that it was best to administer justice over the Javanese population according to their "own" laws and customs. This requirement would be secured in Article 121 of the Regulations of 1819, and in Article 75 of the Regeringsreglement (colonial constitution) in $1854 .{ }^{53}$ There was a tension, however, between the use of local laws in the courtrooms of the pluralistic court and a "longing for certainty" on the other hand, on the part of the Supreme Court. ${ }^{54}$

Although based in Batavia, the Supreme Court's activities impacted the practices of the regional courts because each criminal verdict was sent to the Supreme Court for review, a policy dating back to VOC times, when all verdicts of the landraad of Semarang were sent to the Supreme Court for confirmation. ${ }^{55}$ The Supreme Court held the power to reduce the imposed punishment or even vacate the judgment. ${ }^{56}$ The Supreme Court also circulated guidelines to the lower courts on creating uniformity in the application of criminal law for the local population. They sent their disgruntled remarks on sloppy verdicts to the residents in an effort to achieve more uniformity in the legal system and leave less room for regional diversity.

We must be careful, however, not to see all Supreme Court members as of one mind. In particular, the prominent jurist Pieter Merkus spoke against too much uniformity. He was convinced of the advantages for the Javanese population of a justice system that applied local laws. This was one of the reasons he had pleaded for the introduction of pluralistic courts in the cities. During discussions on this topic he provided the example of buffalo theft, which was to be punished with flogging, branding, and four years on a chain gang labour to colonial regulations. Javanese laws, however, prescribed that if an owner had left his buffalo unsupervised and let them walk around freely in the meadow, buffalo theft would be punished with a mild fine. ${ }^{57}$ Other judges of the Supreme Court were not convinced by this argument. For them the lack of uniformity among landraad verdicts was a major source of concern and they thought it "incomprehensible" that Merkus was not concerned about these regional differences. They gave the example of burglary: one landraad decided on fifty rattan strokes and six months on the chain gang for this crime, whereas another imposed three years of forced labour in similar cases. The Supreme Court also denounced the Regulations of 1819 for leaving too little space to overrule local laws. According to the Supreme Court, this led to "ridiculous verdicts." 58

The Supreme Court has been praised by Dutch legal historians for attempting to moderate the extremely harsh verdicts given to Javanese convicts. ${ }^{59}$ However, it is to be doubted whether this was the incentive of the review system, which rather seems to have been an attempt to maintain some control over the regional colonial administrators. The Supreme Court members were not necessarily against the segregated legal system itself, with its simpler procedures and harsher punishments for the Javanese population, but they were often formalists striving towards uniform practices by the landraden and therefore not in favour of the pluralistic character of the courts. A remarkable aspect of this effort from the perspective of the pluralistic courts was the complete disregard of local Javanese laws and customs, which differed among different Javanese regions. By urging for uniformity throughout Java and 
beyond, the Supreme Court in Batavia actively disregarded the formal colonial policy of applying local laws to the local population.

At the same time, inside the regional courtrooms of the landraden, other dynamics also led to a limited knowledge of local laws and customs on the part of the Dutch residents. References to local laws in court case files seldom go any further than vague descriptions such as "according to the Islamic laws" or "according to the native laws." From the preserved procedural documents, it seems that local advisers advised the Javanese members of court, after which the voting started. Therefore, the Dutch resident probably only communicated with the Javanese court members - the priyayi - about the verdict and not with the advisers directly. The Dutch relied on Javanese intermediaries such as the penghulu, but mainly on the Javanese court members who held the right to vote on the verdict. This might have taken away the necessity for the Dutch to obtain in-depth knowledge on local legal traditions themselves.

\section{Anchoring Colonial Rule}

Despite the Supreme Court's longing for uniformity, and the limited understanding of local legal traditions on the part of Dutch officials and lawyers in general, the pluralistic character of the landraden proved persistent. Until the end of the colonial era the pluralistic colonial courts continued to operate, the Javanese members retained their right to vote on the verdict, and the penghulu continued to provide advice on "native and religious" laws and customs.

This persistence of pluralities at the landraden is exemplary for the policy of dual rule in which Dutch administrators and Javanese priyayi were both responsible for keeping the "peace and order" in the residencies of Java. The landraden could simply not function without the Javanese court members, prosecutor, and religious, Javanese, and Chinese advisers; suspects were only caught with help from the spies of the local priyayi. If the regional elites were not given any influence in the landraad, the court could not function properly. The courtrooms of the landraad were the only place all regional elites met and actively worked together; where they represented and confirmed their power, and possibly even actively influenced their agendas. Historian James Rush, who wrote about the Chinese and opium smuggling, accurately describes the landraad as a site designed for "channeling influences." The interests of the regional elite - in his case the interests of the Chinese Captain in the opium trade and, sometimes, in the smuggling itself-were at least partially represented, because of the Captain's position as an adviser in court. ${ }^{60}$

The pluralistic law courts continued to exist, although simultaneously there was an increasing use of criminal codes based on Dutch colonial laws. Similarly, in often overlapping processes, the dual-rule system of Javanese priyayi and Dutch officials continued to exist while a more centralised colonial state was formed. The Dutch were committed to their official policy of dual rule, and thus relied on the local elites and advisers in administering justice, while simultaneously increasing their direct economic and political influence in Java in the course of the nineteenth century. 
A firm grip on the Javanese population was in particular seen as necessary after the introduction of the cultivation system in 1830, an economic system that relied on the control of the priyayi over the regions. ${ }^{61}$

Legal pluralities were indirectly used by the colonial power to establish their rule and a way of pragmatically using the existing legal systems for the colonial agenda. The early modern history of Europe also shows that regional legal systems were tolerated by centralising powers in order to gain acceptance from the regional and local notables for unification processes. Moreover, legal pluralism was not rejected ideologically either. Therefore, as argued by Philip Stern and Richard Ross, legal pluralism "was not simply about the tension between forward-looking centralising theorists and resistant, pluralistic conditions 'on the ground." 62 A similar process took place in the landraden of Java during the nineteenth century, where pluralities were promoted by colonial administrators and where the regulations explicitly mentioned that the local population would be tried according to their own laws and customs. Over the course of the nineteenth century, the pluralistic landraden would be under discussion every now and then, but until the end of the colonial era, pluralistic colonial courts continued to operate. The jaksa lost his position as an adviser, but still acted as a public prosecutor, and the penghulu continued to provide advice. The Javanese members retained their right to vote on the verdict.

The landraad sessions were visible gatherings, held in white court buildings in the cities or - as happened often in the countryside - outside near the regent's residence or near the site where the crime had been committed. Then, a procession approached on muddy roads, its members on foot or horseback. Former landraad judge C. W. Wormser recalled such an event in his memoirs:

I walked ahead, up the hill through the desa [village], followed by the guards and desa chiefs, then there was, riding a horse, sir Pieters [the registrar], named Don Pietro in his white high-necked coat [toetoepjas] wearing a floppy brown soldier hat; after him—on horses - came the Landraad members, the public prosecutor and the Mahommedan priest. They talked and laughed the entire journey. The procession was concluded by village chiefs, guards, and coolies carrying [pikolden] the luggage and comestibles. ${ }^{63}$

When the party arrived, a courtroom was improvised with the use of a folding screen and a green tablecloth. "We held sessions in an open pondok, constructed beforehand of bamboo, ... or in the open meeting room of the village, or in the porch of the village chief, or in the courtyard of the house where the crime was committed." ${ }^{64}$ Regardless of the exact location of the court session, by spreading a "faded green cloth" on a table, a courtroom was created at once. ${ }^{65}$ Improvised or not, with their green table cloths, court members, advisers, and officials, the pluralistic courts made colonial rule visible in all corners of Java.

\section{Conclusion}

Pluralistic courts in colonial Java were legal spaces within the segregated dual system where colonial and Javanese elites met, administered justice, and assumed control 
over the Javanese population. The landraad in particular, not fitting neatly into the framework of the dual system, proved to be a site where imperial justice was mediated, but also where colonial rule was strengthened and made visible, and thus where the colonial state was gradually consolidated. Wedged between the conflicting aims of the official policy of separate jurisdictions and the unifying ambitions of Supreme Court judges, the Dutch colonial administrators in practice took a different route and deliberately made use of hybridity as a strategy to take control and sustain colonial power.

Legal pluralities were practices that formed the colonial state from below. This process started during VOC times and continued into the nineteenth century. This long-term process and the spatial sites of the landraden are important to research in greater detail, since they reveal not only the conflicts between several layers, institutions, and individuals in the process of colonial state formation but also the importance of local actors in this process. ${ }^{66}$

Little attention has been paid to the practices of law in colonial Indonesia. Historians do not mention local actors, such as the penghulu and jaksa, or only as marginalised figures. ${ }^{67}$ With most emphasis on the late colonial state, legal historians merely focus on how most Dutch administrators and lawyers ignored the "traditional" customary laws of Java until the famous Adat school led by Cornelis van Vollenhoven 'discovered' them in the twentieth century; how the Dutch misinterpreted the Islamic laws and courts (with the exception of some, most prominently Christiaan Snouck Hurgronje); and on how the Dutch early on introduced Western laws into Javanese criminal justice. ${ }^{68}$ What is often missing is both a more in-depth analysis of the longer historical processes prior to the late colonial state and the interactions between Dutch and local legal actors. For example, what were the contacts and conflicts among Javanese and Javanese-Islamic legal traditions and their representatives within the context of colonial law? Such conflicts not only complicated the process of colonial state formation, but also shaped it in the long run.

Legal pluralities did not occur "accidently" at the pluralistic courts, but were consciously and strategically used in criminal law by colonial officials to impose their power and uphold a system of difference and inequality. The long historical process that built the segregated legal system, making use of legal pluralities, deserves closer attention and more historical analysis. A further exploration of the legal space of the landraad is, therefore, an informative subject of study in both the legal and colonial history of Java. ${ }^{69}$ It will provide us with a better understanding of the actual workings of the segregated legal system, of the degree to which local laws and customs were applied in practice, and of the negotiations and conflicts among the various actors within the pluralistic courts.

\section{Bibliography}

\section{Unpublished Primary Sources}

Arsip Nasional Republik Indonesia (ANRI), Jakarta. 
Algemene Sekretarie (AS), (1816) 1819-1942

Gewestelijke Stukken (GS) Tangerang, ca. 1819-1880

Dutch National Archives (NL-HaNA), The Hague.

2.21.007.57 Schneither

2.21.004.19 Van Alphen en Engelhard

Indisch Familiearchief, The Hague.

8 , Familie Hueting.

Leiden University Library (UL), Special Collections.

H 1206, Collectie M. J. A. Oostwoud Wijdenes (1972-1973). "Belevenissen van een rechter in voormalig Nederlands-Oost-Indië." Published before in Tong Tong (1972-1973), book draft, unpublished.

\section{Published Primary Sources}

Chijs, J. A. van der, Nederlandsch-Indisch Plakaatboek 1602-1811. Batavia: Landsdrukkerij, 1885-1900.

Driessen, Alfons Johan. Schets der werkzaamheden in strafzaken van den NederlandschIndischen ambtenaar van het Openbaar Ministerie. Amsterdam: Brinkman \& Zoon, 1897.

Gaijmans, J. J. C. De Landraden op Java en Madura rechtsprekende in Zaken van Misdrijf. Batavia: Van Dorp, 1874.

Haan, Frederik, de. Priangan. De Preanger-Regentschappen onder het Nederlands Bestuur tot 1811, deel 1-4. Batavia: Kolff, 1910-1912.

Heijcop ten Ham, A. J. C. E. van, De Berechting van Civiele Zaken en van Misdrijven op de Terechtzitting der Landraden op Java en Madoera. Leiden: Van Doesburgh, 1888.

Immink, A. J. De regtspleging voor de inlandsche regtbanken in Nederlandsch-Indië, Part 1 and 2. Batavia: Van Dorp \& Co, 1889.

Mijer, Pieter. Verzameling van Instructien, Ordonnancien en Reglementen voor de Regering van Nederlandsch Indie vastgesteld in de jaren 1609, 1617, 1632, 1650, 1807, 1815, 1818,1827, 1830 en 1836. Batavia: Landsdrukkerij, 1848.

Pfyffer zu Neueck, J. J. X. Schetsen van het Eiland Java en deszelfs onderscheidene Bewoners. Amsterdam: Van Kesteren, 1838.

Raffles, Thomas S. The History of Java. 2 vols. London: Black, Parbury and Allen, 1817.

Regeerings-almanak voor Nederlandsch-Indië (RA). Batavia: Landsdrukkerij, 1865-1942.

Staatsblad van Nederlandsch-Indië (S). The Hague: Schinkel; Batavia: Landsdrukkerij, 1816-1940.

Wormser, C. W. Drie en dertig jaren op Java. Deel 1: In de rechterlijke macht. Amsterdam: W. ten Have, 1941.

\section{Secondary Sources}

Abrams, Philip. "Notes on the Difficulty of Studying the State." Journal of Historical Sociology 1:1 (1988): 58-89.

Ball, John. Indonesian Legal History 1602-1848. Sydney: Oughtershaw, 1982.

Bastin, John. The Native Policies of Sir Stamford Raffles in Java and Sumatra: An Economic Interpretation. Oxford: Clarendon Press, 1957.

Benton, Lauren. "Colonial Law and Cultural Difference: Jurisdictional Politics and the Formation of the Colonial State." Comparative Studies in Society and History 41:3 (1999): 563-88. 
Law and Colonial Cultures: Legal Regimes in World History, 1400-1900. Cambridge University Press, 2002.

Bosch, A. G. "Het Openbaar Ministerie in de periode van 1811-1838." In Twee eeuwen Openbaar Ministerie, edited by A. G. Bosch, P. M. Frielink, G. C. Haverkate, M. E. de Meijer and L. Plas. The Hague: Sdu uitgevers/Openbaar Ministerie, 2011.

Briët, C. P. Het Hooggerechtshof van Nederlands-Indië 1819-1848: portret van een vergeten rechtscollege. Amsterdam University Press, 2015.

Burbank, Jane and Fredrick Cooper. "Rules of Law, Politics and Empire." In Legal Pluralism and Empires 1500-1850, edited by Lauren Benton and Richard J. Ross, 279-295. New York: NYU Press, 2013.

Carey, Peter. Daendels and the Sacred Space of Java, 1808-1811: Political Relations, Uniforms and the "Postweg." Nijmegen: Vantillt, 2013.

Comaroff, John L. "Colonialism, Culture and the Law: A Foreword." Law and Social Inquiry 26 (2001): 305-14.

_. "Reflections on the Colonial State, in South Africa and Elsewhere: Factions, Fragments, Facts and Fictions." Social Identities 4:3 (1988): 321-61.

Cooper, Fredrick and Ann Stoler. Tensions of Empire: Colonial Cultures in a Bourgeois World. Berkeley: University of California Press, 1997.

Corrigan, Philip and Derek Sayer. The Great Arch: English State Formation as Cultural Revolution. Oxford: Basil Blackwell, 1985.

Cribb, Robert. "Legal Pluralism and Criminal Law in the Dutch Colonial Order." Indonesia 90 (2010): 47-66.

Fasseur, Cees. "Colonial Dilemma: Van Vollenhoven and the Struggle between Adat Law and Western Law in Indonesia." In European Expansion and Law: The Encounter of European and Indigenous Law in 19th and 20th Century Africa and Asia, edited by W. J. Mommsen and J. A. de Moor, 237-56. Oxford: Berg, 1992.

"Cornerstone and Stumbling Block: Racial Classification and the Late Colonial State In Indonesia." In The Late Colonial State in Indonesia: Political and Economic Foundations of the Netherlands Indies, 1880-1942, edited by Robert Cribb, 31-56. Leiden: KITLV Press, 1994.

Furnivall, J.S. An Introduction to the history of Netherlands India, 1602-1836. Rangoon, 1934.

Goor, Jur van. "Continuity and Change in the Dutch Position in Asia between 1750 and 1850." In Colonial Empires Compared: Britain and the Netherlands, 1750-1850, edited by Bob Moore and Henk van Nierop, 185-200. Aldershot: Ashgate, 2003.

Halliday, Paul D. "Laws' Histories: Pluralisms, Pluralities, Diversity." In Legal Pluralism and Empires 1500-1850, edited by Lauren Benton and Richard J. Ross, 261-78. New York: NYU Press, 2013.

. "Longing for Certainty: Across Law's Oceans." Keynote lecture at the first Ocean of Law conference, Leiden University, 7 December 2015.

Hisyam, Muhamad. Caught between Three Fires: The Javanese Pangulu under the Dutch Colonial Administration, 1882-1942. Jakarta: Indonesian-Netherlands Cooperation in Islamic Studies, 2001.

Hoadley, Mason C. Selective Judicial Competence: The Cirebon-Priangan Legal Administration 1680-1792. Ithaca, N.Y.: Cornell University Press, 1994.

Hussin, Iza R. The Politics of Islamic Law: Local Elites, Colonial Authority, and the Making of the Muslim State. Chicago: University of Chicago Press, 2016.

Lev, Daniel S. "Colonial Law and the Genesis of the Indonesian State." Indonesia 40 (1985): $57-74$. 
Lubis, Nur Ahmad Fadhil. Islamic Justice in Transition: A Socio-Legal Study of the Agama Court Judges in Indonesia. Los Angeles: University of California Press, 1994.

Lukito, Ratno. Legal Pluralism in Indonesia: Bridging the Unbridgeable. Routledge Curzon Contemporary Southeast Asia Series, vol. 48. London: Routledge, 2013.

Lund, Christian. "Rule and Rupture: State Formation through the Production of Property and Citizenship." Development and Change 47:6 (2016): 1199-228.

Niel, R. van. Java's Northeast Coast 1740-1840: A Study in Colonial Encroachment and Dominance. Leiden: CNWS Publications, 2005.

Onghokham. "The Inscrutable and the Paranoid: An Investigation into the Sources of the Brotodiningrat Affair." In The Thugs, the Curtain Thief and the Sugar Lord: Power, Politics and Culture in Colonial Java, 3-73. Jakarta: Metafor, 2003.

—. "The Jago in Colonial Java, Ambivalent Champion of the People." In History and Peasant Consciousness in Southeast Asia, edited by Andrew Turton and Tanabe Shigeharu, Ethnological Studies 13 (1984): 327-43.

Ota, Atsushi. Changes of Regime and Social Dynamics in West Java: Society, State and the Outer World of Banten, 1750-1830. Leiden: Brill, 2006.

Raben, Remco. Batavia and Colombo: The Ethnic and Spatial Order of Two Colonial Cities, 1600-1800. PhD diss., Leiden University, 1995.

Ravensbergen, Sanne. "Courtrooms of Conflict: Criminal Law, Local Elites and Legal Pluralities in Colonial Java." PhD diss., Leiden University, 2018.

Ross, Richard J. and Philip J. Stern "Early-Modern Notions of Legal Pluralism." In Legal Pluralism and Empire 1500-1850, edited by Lauren Benton and Richard J. Ross, 110-13. New York: New York University Press, 2013.

Rush, James. Opium to Java: Revenue Farming and Chinese Enterprise in Colonial Indonesia, 1860-1910. Ithaca: Cornell University Press, 1990.

Saha, Jonathan. "A Mockery of Justice? Colonial Law, the Everyday State and Village Politics in the Burma Delta, c. 1890-1910." Past and Present 217 (2012): 187-212.

Schrikker, Alicia. "Restoration in Java 1815-1830." Low Countries Historical Review (BMGN) 130:4 (2015): 132-44.

Seneviratne, Nadeera T. Negotiating Custom: Colonial Lawmaking in the Galle Landraad. PhD diss., Leiden University, 2016.

Shahar, Ido. "Legal Pluralism Incarnate: An Institutional Perspective on Courts of Law in Colonial and Postcolonial Settings." Journal of Legal Pluralism 65 (2012): 133-60.

Stern, Philip J. The Company-State: Corporate Sovereignty and the Early Modern Foundations of the British Empire in India. Oxford University Press, 2011.

Sutherland, Heather A. The Making of a Bureaucratic Elite: The Colonial Transformation of the Javanese Priyayi. Singapore: Heinemann, 1979.

Termorshuizen-Arts, Marjanne. "Revisie en Herziening: De Continuïteit in de Indonesische Rechtspleging." Bijdragen van het Koninklijk Instituut voor Taal-, Land- en Volkenkunde 150:2 (1994): 330-56.

Wamelen, Carla van. Family life onder de VOC. Een handelscompagnie in huwelijks- en gezinszaken. Hilversum: Verloren, 2014.

\section{Notes}

* Sanne Ravensbergen is a historian of colonial Indonesia, based as postdoctoral researcher at the Institute for History at Leiden University. Her research focuses on the practices and ideologies of colonial law, legal pluralism, colonial liberalism, local elites, the material culture of courts, and legal professionals.

1 Driessen, Schets der werkzaamheden in strafzaken, 35; RA 1834, 45. Generally, 
jaksas originated from the Javanese priyayi class, but exceptions were made in multicultural Batavia, which lacked a Javanese priyayi class. The exact ancestry of Johan Abiedien Naija Gatie is unknown.

2 RA 1834, 45. Penghulu was in Java the title of the highest-ranking religious official.

3 S 1819, no.20, art.120.

4 ANRI, GS, Tangerang. N0.27.III.

5 Regarding criminal law, the landraad administered justice in cases of crimes that were not severe enough to be sent to the circuit court, and offences for which fines of fifty to five hundred guilders or more than three months in prison could be imposed. The circuit court (ommegaande rechtbank) was a travelling law court which adjudicated all crimes for which the suspect could receive the death penalty. In 1901 the circuit courts were abolished and thereafter all criminal cases were decided by the landraden.

6 Immink, De regtspleging voor de inlandsche regtbanken. Part 1, 105-22.

7 Halliday, "Laws' Histories," 267. Halliday has argued for the use of "legal pluralities" instead of "legal pluralism" to place practice rather than the state at the centre of analysis, which itself was formed by practice.

8 The Netherlands Indies' archives (1800 1942) offer a challenge when studying legal history, since, as far as is known, all archives of colonial law courts are lost. The nineteenth-century law journals have been preserved, but these were only published after 1848 and provide limited information about the actual criminal law practices of the pluralistic courts. However, administrative archives in Jakarta and The Hague provide a rich variety of sources, including a number of preserved procedural documents.

9 Cribb, "Legal Pluralism," 47-66; Lev, "Colonial Law," 57-60. Legal anthropologists of Indonesia did use the frameworkof legal pluralism in a broader, more dynamic way, and often also devote some attention to policies (though not practices) inthe colonial period; see for example Lukito, Legal Pluralism in Indonesia.

10 Shahar, "Legal Pluralism Incarnate," 135. Shahar argues for a more institutional approach to legal pluralism.

11 For research on the transitional era from company-state to colonial state see Schrikker, "Restoration in Java," 132 44; Van Niel, Java's Northeast Coast; Van Goor, "Continuity and Change"; Ota, Changes of Regime; Stern, The Company-State.

12 Lund, "Rule and Rupture," 1199-201; Abrams, "Notes," 76.; Corrigan and Sayer, The Great Arch, 10.

13 Comaroff, "Reflections on the Colonial State," 345-6; Benton, "Colonial Law and Cultural Difference," 564, 586.; Hussin, Politics of Islamic Law, 10, 12 3, 30-2.

14 Cooper and Stoler, Tensions of Empire, 20-2.

15 The indirectly-ruled princely lands (Vorstenlanden, the sultanates of Central Java) followed a different course of state formation and are beyond the scope of this research.

16 Sutherland, The Making of a Bureaucratic Elite, 2.

17 See for example Onghokham, "The Jago in Colonial Java"; Onghokham, "The Inscrutable and the Paranoid."

18 Cooper and Stoler, Tensions of Empire, 37.

19 Halliday, "Laws' Histories," 268.

20 Benton, Law and Colonial Cultures, 127.

21 Raben, Batavia and Colombo, 200-3.

22 Bosch, "Het Openbaar Ministerie," ch.1, para. 2. This number quickly decreased during the nineteenth century when uniformity was introduced through the nationwide implementation of French legislation.

23 Van Wamelen, Family life, 76. Formally, from 1621 onwards, according to the principle of concordance (concordantiebeginsel), Roman Dutch law was followed in Dutch governed areas of Java, 
but with the additional principle that this would be the case insofar as possible and practical. This provided space for the application of Javanese customary and Islamic laws.

24 Ball, Indonesian Legal History, 57.

25 Rupesinghe, Negotiating custom, 69.

26 Van der Chijs, Nederlandsch-Indisch Plakaatboek, part 5, 525-26. Placcate "Oprigting van een landraad te Semarang/" 30 November 1747.

27 De Haan, Priangan, part 4, 417. For a discussion on the assumed Islamic character of the Semarang Compendium, see the article by Mahmood Kooria in this issue.

28 Hoadley, Selective Judicial Competence, 124, 145.

29 Ball, Indonesian Legal History, 62-3; Lubis, Islamic Justice in Transition, 60.

30 Asian Charter, 1803, Art. 86. In Mijer, Verzameling van instructien.

31 Landraden were presided over by the (assistant) resident until 1869, when "independent" judicial officials began presiding over the courts. The Javanese court members, however, remained priyayi with executive powers in the region until the end of colonial times.

32 Carey, Daendels and the Sacred Space, 3.

33 NL-HaNA 2.21.004.19 Van Alphen en Engelhard 019A, n0.259. "Memorie Instructif: Derde afdeeling Regterlijke Magt," art. 1, 2, 9, 11 and 14.

34 Ota, Changes of Regime 147; Van der Chijs, Nederlandsch-Indisch Plakaatboek, 16, 417-8.

35 Heijcop ten Ham, De Berechting van Civiele Zaken, 6.

36 Bastin, Native Policies, 45-6.

37 Raffles, History of Java, 321.

38 Regulation A. D. 1814, art.100.

39 Regulation A. D. 1814, art.159.

40 Furnivall, An Introduction to the History of Netherlands India, 62.

41 S 1819/20.

42 S 1824, n0.4.

43 S 1819/20, art.121.

44 R. O. 1846, art.7.
45 Gaijmans, De Landraden op Java, Appendix 1.

46 Gaijmans, De Landraden op Java, 7.

47 Pfyffer zu Neueck, Schetsen van het Eiland Java, 154.

48 ANRI, GS Tanggerang, n0.27.III. Landraad sessions held in Mr. Cornelis in the South quarters of the Environs of Batavia: 5-11-1834, 19-11-1834, 26-11-1834, 312-1834, 10-12-1834 and 17-12-1834. All were theft cases.

49 RO, 1846, art.91.

50 See for example Indisch Familiearchief, n0.8, Hueting. Letter Kees to his parents in law. Blitar, 7 April 1920.

51 Ravensbergen, "Courtrooms of Conflict," 107.

52 ANRI, GS Tangerang, n0.27.I. Criminal case Oetang Bappa Leha. West Quarters of the Ommelanden of Batavia, 16 January 1826.

53 S 1819, n0.20.; RR 1854, art.75.

54 Halliday, "Longing for Certainty"; Burbank and Cooper, "Rules of Law," 279-89.

55 Gaijmans, De Landraden op Java, 2; Heijcop Ten Ham, De Berechting van Civiele Zaken, 32n2.

56 Termorshuizen-Arts, "Revisie en Herziening," 331, 336-37; Ball, Indonesian Legal History, 180; S 1819, n0.20. "Instructie voor het Hoog Geregtshof van Nederlandsch-Indië,” art. 56 and 57. After 1901, review was done by the Councils of Justice.

57 NL-HaNA 2.21.007.57 Schneither, no.14. Letter, attorney general to the supreme court. Batavia, 16 July 1821.

58 NL-HaNA 2.21.007.57 Schneither, no.14. Report, Supreme Court. Batavia, 16 januari 1822.

59 Termorshuizen-Arts, "Revisie en Herziening," 339; Briët, Het Hooggerechtshof van Nederlands-Indië, 143.

60 Rush, Opium to Java, 109.

61 Fasseur, "Cornerstone and Stumbling Block," 34.

62 Ross and Stern, "Early-Modern Notions of Legal Pluralism," 110-3. 
63 Wormser, Drie en dertig jaren op Java, 35. Wormser was a landraad president in Java during the early 20 th century.

64 Ibid.

65 Oostwoud Wijdenes, "Belevenissen van een rechter in voormalig NederlandsOost-Indië," 11.

66 Saha, "A Mockery of Justice?" 190-1; Comaroff, "Colonialism, Culture and the Law," 305-14. Jonathan Saha and John Comaroff call for more focus on the dynamics of colonial legal institutions in the British imperial context order to understand the colonial state and its legitimacy.

67 An exception to this is of Muhamad Hisyam, Caught between Three Fires, a rich study on the social position of the penghulus and the considerable changes in their position during the late nineteenth century.

68 See for example Fasseur, "Colonial Dilemma,"; Ball, Indonesian Legal History of.

69 Ravensbergen, "Courtrooms of Conflict." 